\title{
Gerencsér Péter
}

\section{Bársonyos (re)generáció: Az új szlovák dokumentarizmus az ezredforduló után}

\begin{abstract}
Absztrakt
A tanulmány az „új szlovák dokumentarizmus” fogalmának bevezetésével azokat a dokufikciókat vizsgálja, amelyek közvetlen alapjait az úgynevezett 90-es nemzedék teremtette meg. A dolgozat amellett érvel, hogy a szlovák film korszakváltása nem 1989-ben vette kezdetét, majd szélesebb nemzetközi filmtörténeti keretbe ágyazza az új szlovák dokumentarizmus mozgalmát. Ezt követôen a nem-fikciós dokumentumfilm fikciós filmmé történő átalakulását a Môj pes Killer és az Eva Nová címú filmeken keresztül követi nyomon. Végül a kortárs szlovák film nemzetközi párbeszédképességét a posztkoloniális (film)elméletek alkalmazhatóságának lehetôségein keresztül vizsgálja, és azt a Zvonky štastia és a Cigáni idú do volieb címú roma tematikájú filmeken teszteli. A szerző arra a következtetésre jut, hogy a mozgalom új életre keltette a szlovák filmet, így az „második szlovák újhullámnak” nevezhetô el.
\end{abstract}

\section{Szerzó}

Gerencsér Péter a Milton Friedman Egyetem (Budapest) Kommunikáció- és Múvelôdéstudomány Tanszékének fôiskolai docense. Tudományos kutatási területei: digitális kultúra, újmédiamúvészet, cseh és szlovák film, közép-európai animációs film.

https://doi.org/10.31176/apertura.2021.17.1.4 


\section{Gerencsér Péter}

\section{Bársonyos (re)generáció: Az új szlovák dokumentarizmus az ezredforduló után}

Stanislava Spáčilovának

\section{9 vagy 2009 ?}

A közép-európai ${ }^{[1]}$ filmtörténettel foglalkozó tanulmányok, összefoglalók és folyóiratok a „kortárs film” fogalmát konvencionálisan a keleti blokk összeomlásának dátumához, az 1989-es rendszerváltásokhoz, Csehszlovákia esetében a bársonyos forradalomhoz kapcsolják. Másként fogalmazva: ebben a filmtörténeti diskurzusban a kortárs film fogalma a kommunista rendszer utáni korszakkal azonosítódik. Ewa Mazierska a közép- (és/vagy kelet-) európai filmrôl általánosságban szólva a „régi és az új megközelítések” közötti válaszvonalat a politikai-gazdasági környezet megváltozásában látja a Studies in Eastern European Cinema címú folyóirat programadó tanulmányában, melyben többször is „1989 elôtti” és „1989 utáni” idôszakra osztja a térség filmtörténeteit. ${ }^{[2]}$ Ezt a gyakorlatot követi a cseh és a szlovák filmrôl szóló szintézisében Peter Hames, aki a rendszerváltás utáni legismertebb szlovák rendező, Martin Šulík múveit az „1989 utáni [...] rendezốk" keretében tárgyalja. ${ }^{[3]}$ Martin Palúch a kortárs szlovák dokumentumfilm tárgyalásának kezdőpontját szintén 1989-ben adja meg. ${ }^{[4]}$

Kétségtelen, hogy a közép-európai filmmúvészetek történetében jelentôs határpontot képeznek az 1989-es rendszerváltások, mert a politikai átalakulás zavaros piacgazdasági és lassú kulturális átalakulással járt együtt, ideértve a korábbi filmgyártási, terjesztési struktúra új alapokra történô helyezésének szükségességét is. Amint Peter Hames Csehszlovákia összefüggésében írja: [a] „kommunizmus bukása elkerülhetetlen válságot idézett elố a termelésben, különösen azáltal, hogy a kormány minden állami támogatást virtuálisan elvont, és a jelenlegi ${ }^{[5]}$ elnök, Václav Klaus hírhedt szavaival szólva, a filmiparban "minden megy tovább a régi kerékvágásban «". [6] Ugyanakkor a szlovák filmtörténész, Jana Dudková arra figyelmeztet, hogy 1989 nem jelent éles vízválasztót a szlovák filmtörténetben, mivel a korábbi formai, szemléletmódbeli sajátosságok a bársonyos forradalommal nem egy csapásra értek véget, míg az új tendenciák még nem kezdôdtek el. ${ }^{[7]}$ Dudková a változásra való felkészületlenségben és a filmek megkésettségében megtestesülô temporális feszültséget úgy konkretizálja, hogy egyrészt az „ideológiai nyomás [...] nem változott meg drámaian 1989 után sem”, ${ }^{[8]}$ másrészt a még azelôtt készült „filmek, melyek csak a forradalom után jelentek meg, emiatt »anakronisztikusak« váltak”. [9] 
A politikai rendszerváltás és a filmtörténeti korszakváltások aszinkronitása nem korlátozódik a szlovák filmkultúrára, az idôbeli eltolódás megfigyelhetô egész Közép-Európában. Magyarországon a filmtörténészek álláspontja szerint az 1990-es évek filmjeinek tematikai-stilisztikai ismérvei kontinuitást mutatnak az 1980-as évekével, és csak egy évtizeddel a rendszerváltás után következik be filmmúvészeti fordulat a játékfilmben. Ezt az újfajta érzékenységet Gelencsér Gábor nyomán a magyar filmtörténet „fiatal magyar filmnek” keresztelte el. ${ }^{[10]}$ Romániában a 2001-ben szinte belsố elôzmények nélkül indult, „román újhullám” (Noul val românesc) néven ismert mozgalom nemcsak a román filmtörténeten belül vált meghatározóvá, hanem az ezredforduló utáni európai filmkultúrának is az egyik legizgalmasabb fejezetét képezi. [11 ] A cseh filmben a múlthoz való viszony megváltozása, a korábban domináns, megbocsátó nosztalgikus retrófilm helyére a számonkérô történelmi film az ezredforduló után lépett. A legutóbbi szintézis szerint az ezredforduló utáni lengyel filmben a populáris múfajok megerôsödése mellett hasonló mozgás figyelhetô meg, a „szent” nemzeti témák és a katolicizmus korábbi patetikus-romantikus ábrázolását a demisztifikáció és a kritikai attitúd váltotta fel. [12] Ezen kiválasztott példák alapján Közép-Európában a formai értelemben a filmtörténeti korszakváltás a politikai klímaváltozás után mintegy egy-másfél évtizedes késéssel következett be, ami transznacionális keretbe ágyazza a szlovák film 1989 utáni történetét is.

Érdemes tehát a „kortárs szlovák film” fogalmát eloldani a bársonyos forradalom évétôl. A rendszerváltás óta harminc esztendô telt el, ami megkérdôjelezi, hogy egy ilyen tág idôperiódust azonos politikai, kulturális és filmtörténeti egységként kezeljünk. Másrészt a szlovák film 1990-2020 közötti idôszakát tekintve is megfigyelhetô az a belsô cezúra, amely más középeurópai nemzeti filmes gyakorlatokat is jellemez. Ennek következtében a korábbi interpretációs gyakorlatokkal szemben - az eltérô intézményi, financiális és esztétikai tulajdonságok miatt - nem a rendszerváltástól kezdôdô idôszakot tekintem „kortárs szlovák filmnek”.

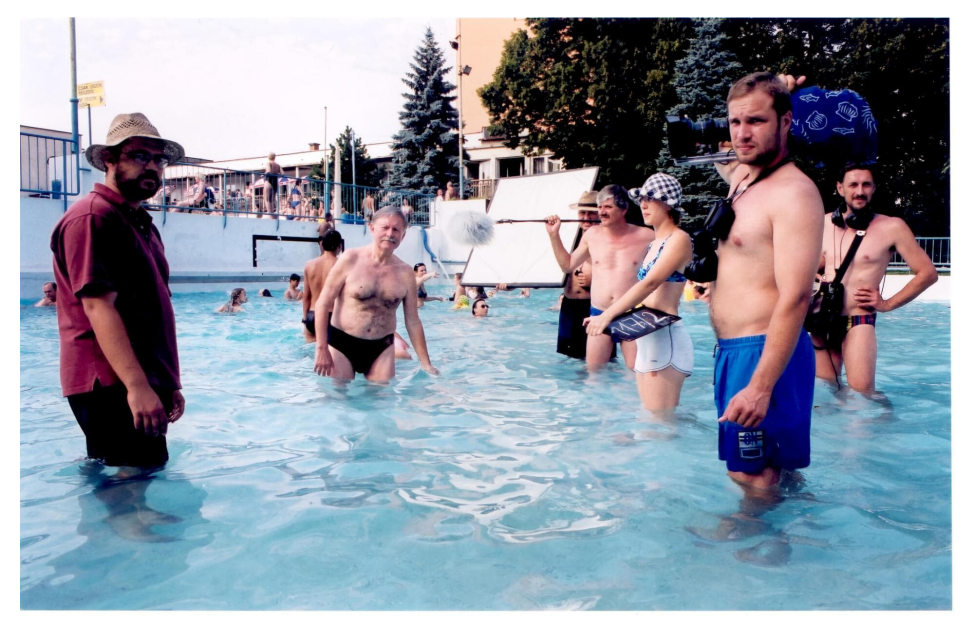

66 szezon

Nem egyszerú kérdés azonban, hogy melyik évszám jelölhetố ki az új szakasz kezdôpontjául. A Szlovák Audiovizuális Alap (Audiovizuálny Fond) 2009-ben történt létrehozása alapvetô fordulatot hozott a szlovák nemzeti filmgyártás finanszírozásának stabilizációjában és a tervezhetôségben. 
Ahhoz, hogy létrejöttének jelentôségét aláhúzhassuk, az Alap újfajta finanszírozási modelljét a korábbi gyakorlatok fényében kell értelmezni. Az 1990-es években az elapadó állami támogatások miatt az önálló szlovák filmgyártás a megszúnés szélére került, évente csupán néhány játékfilmet sikerült befejezni, azt is többnyire nemzetközi együttmúködés keretében. Ez kialakította azt a toposzt, hogy a szlovák film egy fantom, nem is létezik. Csehszlovákia 1993-as szétválása után a helyzetet súlyosbította, hogy Vladimír Mečiar harmadik miniszterelnöksége (1994-1998) idején az elsó önálló szlovák játékfilmstúdióként 1949-ben alapított, de 1953-tól múködô pozsonyi Koliba Filmstúdiót (Filmové ateliéry Koliba) 1995-ben gyanús körülmények között privatizálták, melynek következtében a stúdió de facto megszúnt. A privatizáció egy nagyobb folyamat része volt, melyról a történész Dušan Kováč megjegyzi: „A kormánykoalíció a privatizációt közvetlen eladás útján folytatta saját híveinek körében, holott a privatizáció véghezvitelével nem a kormány, hanem a Nemzeti Vagyonalap volt megbízva.” [13] A permanens filmgyártási problémákon a Szlovák Audiovizuális Alap nemcsak a támogatási összegek növelésével enyhített, hanem azáltal is, hogy szakmai önigazgatás, elszámoltathatóság, a pénzösszegek rugalmas felhasználhatósága és transzparens döntéshozatal jellemzi. ${ }^{[14]}$ Ezért Jana Dudková egyfajta korszakküszöbnek látja az új financiális modell bevezetését: „Csak 2009-ben változott meg a helyzet a Szlovák Audiovizuális Alap létrejöttével”. [15]

Ezek alapján szervezeti-pénzügyi szempontból 1989 helyett a húsz évvel késóbbi évhez, 2009-hez kapcsolható a kortárs szlovák film belsô fejlődésében beállt változás. A tematikai-formai elmozdulás azonban már korábban látható vált a szlovák filmtörténetben, vagyis az intézményi struktúrában bekövetkezett fordulópontot megelôzte egy kulturális átalakulás, mely az úgynevezett „90-es nemzedékhez” köthető.

\section{A 90-es nemzedék}

A szlovák filmtörténetben az új szakaszt nem annyira az 1989-es bársonyos forradalom és nem is a 2009-es újfajta támogatási rendszer bevezetésének keretfeltétele jelentette, hanem a kétezres évek első felében megjelenô új rendezői problémaérzékenység. Nem a „régi” és az „új” gyakorlatok közötti éles váltásról, sokkal inkább lassú folyamatról beszélhetünk, amely a kontinuitás és a diszkontinuitás dialektikája mentén formálódott. Így nem feltétlenül célravezetô a korszakváltás kezdôpontját egyetlen évszámmal megjelölni. A kezdetet az új évezred első éveihez köthetjük, és a tendenciákat az Audiovizuális Alap megalapítása csak felgyorsította. A „fiatal magyar filmhez” és a „román újhullámhoz” hasonlóan az új korszak Szlovákiában is generációs jellegú, amit Pavol

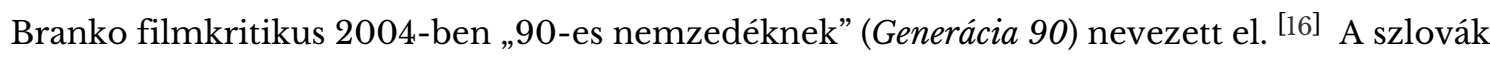
filmben a filmrendszerváltást lényegében a 90-es nemzedék múvei hajtották végre. Ez a nemzedék teremtette meg az alapjait a kortárs szlovák film nemzetközi láthatóságának. A heterogén összetevőkből álló változás megértése szélesebb idôbeli kontextust igényel.

\section{Hogyan fö a történelem?}


Az 1990-es években a szlovák film Jana Dudková által említett „anakronizmusából” és „megkésettségéböl”, vagyis az egyetemes trendektôl való lemaradásából lényegében egyetlen rendező volt képes kitörni: Martin Šulík. A rendszerváltás utáni elsô évtized filmkultúrájáról szóló diskurzusok visszatérô motívuma, hogy még az önálló szlovák film létét is elvitatták, vagy - a korábbi paternalista retorikát megismételve - a szlovák filmet a csehek „kisebb testvérének“ állították be. Peter Hames a szlovák filmgyártás haláláról, Prágába „emigrált" vagy cseh pénzből filmet készítô rendezókrốl (Juraj Herz, Juraj Jakubisko, Dušan Hanák, Martin Šulík) beszélve azt állítja, hogy a szlovák film a cseh film árnyékában maradt. ${ }^{[17]}$ Šulíknak a hatvanas-hetvenes évek „szlovák újhullámával” (Slovenská nová vlna) ${ }^{[18]}$ is párbeszédképes játékfilmjei, különösen a Minden, amit szeretek (Všetko čo mám rád. 1993), A kert (Záhrada. 1995) és az Orbis Pictus (1997) szinte egyedüliként képviselték Szlovákiát külföldön. Mellette jóformán csak a Mečiar-éra politikai (és gazdasági) viszonyaira szatirikus módon reflektáló Rivers of Babylon (Vladimír Balco, 1998) címú filmje érte el a nemzetközi érdeklődés ingerküszöbét. A 2000-es években fellépő 90-es nemzedék azonban újra felhelyezte a térképre az önálló szlovák filmet. Adatbázisok (sfu.sk, aic.sk), folyóiratok (Kino-Ikon, Film.sk, Kinečko, Vlna, CinemaView), fesztiválok (1999-tôl a pozsonyi Medzinárodný filmový festival, 2007-tôl a Filmový festival inakosti queer-fesztivál, 2008-tól a Fest Anča animációs seregszemle, a vizsgafilmes Skrátka študenti), tudományos kutatóprogramok, DVDkiadások és külföldi filmhetek is jelzik az intézményi regenerálódást.

A Generácia 90 azokra az alapvetôen dokumentarista érdekeltségú rendezókre utal, akik a kilencvenes években kezdték pályafutásukat, de a 2000-es években érték el elsô jelentôsebb hazai és nemzetközi sikereiket. Alkotásaikkal éppen azt az úrt töltötték be sikeresen, amit a 90-es években a filmkritikusok hiányoltak a szlovák filmbôl, nevezetesen a kortárs társadalmi viszonyok reflexióját. Jana Dudková ezt a deficitet így fogalmazza meg: „Ennélfogva nem meglepő, hogy végül az a vélemény terjedt el a szlovák filmkritikusok, filmrendezők és nézők között az 1990-es években, hogy a szlovák film nem képes tükrözni a fôbb társadalmi és politikai kérdéseket, legyenek azok a jelenben vagy a múltban". ${ }^{[19]}$ Ennek fényében aligha véletlen, hogy a korrupciót és a hatalomvágyat célkeresztjébe állító Rivers of Babylon parabolája aratott sikert az értelmiség körében, mert a hiányolt politikai kommentár vágyának tett eleget. Amíg azonban Balco filmje játékfilmes eszközökhöz nyúlt, addig a Generácia 90 döntôen a dokumentarista formát választotta. Jaroslav Vojtek, Pavol Barabáš, Marek Šulík, Marko Škop, Juraj Lehotský, a kassai (magyar és szlovák identitású) Kerekes Péter / Peter Kerekes, valamint a filmjei miatt [A harmadik hatalmi ág betegsége, (Nemoc tretej moci. 2011); Ficótól Ficóig, (Od Fica do Fica. 2012)] politikai támadások kereszttüzébe került Zuzana Piussi, a „szlovák Michael Moore” nevét ez fúzi össze. Pavel Branko, a „90-es nemzedék” fogalmának megalkotója nem tudományos tanulmány, hanem esszé keretében írta körül a mozgalmat, és a technikai feltételek változásának függvényében a szubjektív megközelítést és a rendezôi jelenlét felerôsödését hangsúlyozta. [20]

Žofia Bosáková tanulságos áttekintést nyújt a Generácia 90 fogalmának recepciótörténetérôl és a Pavel Branko szövegét érintô kritikákról. ${ }^{[21]}$ Noha a mozgalom generációs jellegét elfogadták, a „90-es” számot problémásnak tekintették, mivel nem volt világos, hogy esszéjében Branko a 
szerzôk debütálását vagy az átalakuló évtizedet értette-e rajta, továbbá permanens problémát jelentett a dokumentumfilm és a hitelesség fogalmának képlékenysége. Martin Kaňuch 2008-ban publikált Jobb kezdet: A szlovák dokumentumfilm 15 éve (Lepši začiatok. 15 rokov slovenského dokumentárneho filmu) címú tanulmányában azon túl, hogy a politikailag elkötelezett 98 hangja (Hlas 98. Marek Kuboš, 1998) filmtörténeti helyét mérlegelte, azt emelte ki, hogy ezekben a jelenorientált vagy a szubjektív történelmet elôtérbe helyezô dokumentumfilmekben a játékfilmekre jellemzô módszerek is helyet kapnak. ${ }^{[22]}$ Tomáš Hučko a társadalmi aspektusokra fókuszált, és amikor a dokumentarista megfigyelés és a kreatív alkotás párosításáról értekezett, a fikciós elemeket domborította ki. ${ }^{[23]}$ Nagyívú monográfiájában Martin Palúch a szubjektív elemek elôtérbe kerülése révén a meghatározó vonásnak a szerzôiséget tekintette. ${ }^{[24]}$ Végsô soron tehát a „90-es nemzedék” terminus szlovák filmtörténeti recepciójában mindig is jelen volt a fikció és a dokumentumfilm keveredésének felismerése, még ha nem is ez a téma uralta a kritikai diskurzust.

Az említett rendezôk teremtették meg az általam „új szlovák dokumentarizmusnak” nevezett, heterogén elemekból álló irányzatot. Amíg ugyanis Pavel Branko a 90-es nemzedék fogalmát az azonos életkorban lévô dokumentumfilm-készítôkre alkalmazta, magam az új szlovák dokumentarizmust idôben és formailag is szélesebb értelemben használom. Branko 2004-ben egy új filmes tendenciának még szükségszerúen csak a formálódását tudta körvonalazni, a mából visszatekintve azonban eltérô perspektívából láthatók az akkori és az azóta eltelt idô alatt született filmek. Az „új szlovák dokumentarizmus” fogalma ezért egyrészt túllép a generációs meghatározottságokon, a 90-es nemzedék alkotóin kívül magába foglal olyan fiatalabb vagy késôbb induló rendezôket is, mint Mira Fornay, Prikler Mátyás, Iveta Grófová, Mária Rumanová vagy Ivan Ostrochovský, így lazább szerzôcsoportot jelent, mint a nemzedék. Másrészt Branko megközelítésével szemben a dokumentumfilmek mellett felölel játékfilmként bemutatott munkákat is, emiatt használom a „dokumentarizmus” terminust a szúkebb „dokumentumfilm” helyett. Az új szlovák dokumentarizmust a társadalmi elkötelezettség, továbbá az abroncsolja össze, hogy a szerzốk a filmjeikben a dokumentarista és a fikciós módszereket keresztezik egymással.

Kérdés, mennyiben tekinthetố korszaknak, filmes mozgalomnak vagy iskolának az új szlovák dokumentarizmus. Habár a szerzôk életkorát tekintve nemzedékinek indult, utóbb fiatalabb szerzôkkel bôvült, és sem stilárisan, sem pedig múfajilag nem tekinthetố egységes csoportnak. Kerekes elôzetes forgatókönyv alapján megtervezett és távolságtartó filmjei például távol állnak Piussi oknyomozó videó-újságírásától és politikai elkötelezettségétôl. Nincsen közös programjuk sem, noha például az olyan többszerzôs szkeccsfilmek, mint a Szlovákia 2.0 (Slovensko 2.0. Ondrej Rudavský, Martin Šulík, Viera Čákanyová, Zuzana Liová, Mišo Suchý, Juraj Herz, Miro Jelok, Peter Krištúfek, Iveta Grófová, Peter Kerekes, 2014) vagy a Bársonyos terroristák (Zamatoví teroristi, Peter Kerekes, Ivan Ostrochovský, Pavol Pekarčík, 2013) emlékeztetnek a 60-as évekbeli európai modernizmus programszerúnek tekinthető omnibuszfilmjeire, mint a RoGoPaG (Jean-Luc Godard, Ugo Gregoretti, Pier Paolo Pasolini, Roberto Rossellini, 1963) és a Gyöngyök a mélyben (Perličky na dně. Jiří Menzel, Jan Němec, Evald Schorm, Věra Chytilová, Jaromil Jireš,1963). Az „új 
szlovák dokumentarizmus" kifejezéssel a továbbiakban mint laza szerzôi csoportra, nem pedig mint generációra vagy iskolára fogok utalni.

Az új szlovák dokumentarizmus vagy posztmodern módon a dokumentumfilm szabályaival játszik [66 szezon (66 sezón. Kerekes Péter, 2003)], vagy a non-fiction és a játékfilm ötvözete [ Köszönöm, jól (D̆akujem, dobre. Prikler Mátyás, 2013)]. Megfigyelhetô továbbá az a tendencia is, hogy a dokumentumfilmesekból játékfilm-rendezók lesznek (Jaroslav Vojtek, Marko Škop). Az új szlovák dokumentarizmus irányzata belsô elózményként nyúlhatott vissza a hatvanas-hetvenes évek szlovák újhullámának tradícióihoz, különösképpen Dušan Hanák filmjeihez (322. [1969]; Egy régi világ képei [Obrazy starého sveta. 1972]), egyúttal azonban elöre is vetítette azokat a legutóbbi idôben felerôsödô múfaji-formai áramlatokat, melyek a játékfilmet dokumentarista és minimalista eszközökkel kombináló filmeket eredményeztek.

\section{A fikciós dokumentarizmustól a dokumentarista fikcióig}

Meglátásom szerint az „új szlovák dokumentarizmus” jellemzôi rajzolják ki a kortárs szlovák film meghatározó vonásait. A dokumentarizmusnak a dokumentumfilmnél szélesebb kategóriáját azért használom ezekre az alkotásokra, mert - mint említettem - nemcsak a dokumentumfilmek használnak játékfilmes elemeket, hanem fordítva is, illetve a rendezôk elóbb dokumentumfilmet, utóbb pedig dokumentarista játékfilmet készítenek. A 90-es nemzedék által elindított sajátos formakombináció mind idôben, mind térben tágabb nemzetközi összefüggésekbe illeszthetô.

Mint azt máshol a szlovák film transznacionalitása kapcsán kifejtettem, szükség volna egy olyan, jelenleg hiányzó közép-európai filmkomparasztikai szemlélet meghonosítására, amely nem pusztán a nemzeti sajátosságokra figyel, hanem regionális, transznacionális, posztkoloniális keretben is gondolkodik. ${ }^{[25]}$ Nemcsak azért, mert Közép-Európa alapvetôen multietnikus régió, hasonló történelmi tragédiákkal, ahol az államhatárok folyton változtak, és burjánzanak a kötôjeles / akcentusos identások, hanem azért is, mert a nemzeti filmtörténetek összehasonlítása, a hasonló vagy ellentétes tendenciák, hiányok, önreprezentációs módok vizsgálata révén egymáson keresztül végsố soron saját partikuláris kulturánk mozgatórugóit is mélyrehatóbban érthetnénk meg. Az új szlovák dokumentarizmus céljait és módszereit tekintve párhuzamba állítható a lengyel „fekete szériával" (czarna seria), a cseh újhullám mikrorealista vonulatával, a magyar Budapesti Iskolával, a román újhullámmal, de, még inkább tágítva a kört, az olasz neorealizmussal, cinéma verité mozgalommal, a free cinemával, sôt a dán dogmafilmmel és Ulrich Seidl és Michael Haneke tartózkodó stílusával is. Filmkomparatisztikai keretben közülük most két közép-európai kapcsolatra koncentrálok. 


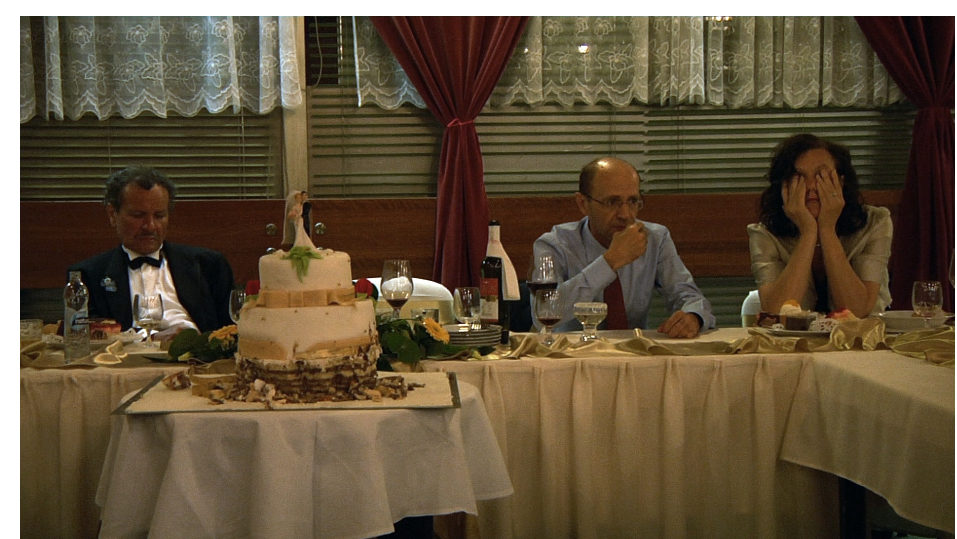

Köszönöm, jól 
Először is, a fikciós és a nem fikciós elemeknek a keveredése a kortárs szlovák filmben feltûnően hasonlít az 1970-es évek magyar filmtörténetének szociológiai érdeklôdésú irányzatára, amit „fikciós dokumentarizmusnak“, vagy más néven Budapesti Iskolának keresztelt el a filmtudomány. [26] A Budapesti Iskola kanonikus filmjeiben a valóság dokumentálásának szándéka a fikciós filmekre jellemzô elemekkel (narratív szerkesztettség, dramatizálás, tervezett szituációk)ötvöződik, ahol a 60-as évek játékfilmjeinek moralizáló-publicisztikus felfogását a kisemberekrekoncentráló analitikus-leíró elv váltja fel. Miközben nem létezett szigorú értelemben vettforgatókönyvük, a többnyire saját magukat eljátszó szereplôk vagy amatôr színészek a kameraelôtt improvizáltak (Dárday István és Szalai Györgyi: Jutalomutazás. 1974; Schiffer Pál: Cséplö Gyuri.1978). A szlovák filmben például ez figyelhetô meg Peter Kerekes 66 szezonja esetében, melybenegy kassai strand az emlékezés helyévé válik, és ahol a fôszereplô a rendezô nagymamája. Aposztkoloniális elméletek fényében a régió történelmének metaforájaként interpretálta a filmetJana Dudková. ${ }^{[27]} \mathrm{Az}$ ételekhez metaforikus asszociációk kapcsolódnak Kerekes másik, Hogyan fö a történelem? (Ako sa varia dejiny. 2008) címú filmjében is, amit behatóan Mária Ferenčuhovávizsgált. ${ }^{[28]}$ Mint azt máshol számba vettem, Kerekes filmjeinek hibriditása a reflexívdokumentarizmus elidegenítô hatásából, a múlt újrajátszásából, a(z) (ál)naiv interjúkészítésimódszerból, az asszociatív montázsból és a groteszk humorból fakad. ${ }^{[29]}$ Munkái le is leplezik adokumentarizmust, a 66 szezon például Dziga Vertov módján erôsen önreflexív, magának afilmkészítésnek a folyamatát is megjeleníti: mindvégig megmutatja az esetlegességet, a képbefolyton belóg a mikrofon, illetve helyet kap benne a rendezôi utasítás, vagyis azok az elemek,melyeket rendszerint ki szoktak vágni. A dévényi mészárlás (Devinsky masaker. Gejza Dezorz, 2011)címú részint (re)konstruált dokudráma a nem fikciós elemeket szintén fikciós megoldásokkalvegyíti. Ahogyan a Budapesti Iskola keretén belül Tarr Béla Családi tûzfészek (1977) és Szabadgyalog(1980) címú fikciós dokumentumfilmjeiból fejlődött ki Tarr jellegzetes játékfilmstílusa (hosszúbeállítás, lassú kameramozgás, állapotszerú narratíva) a kortárs szlovák filmben Marko Škopmultietnikus tematikájú, riportszerú dokumentumfilmjei (Más világok [Iné svety. 2006]; Telepóc [Osadné. 2009]) minimalista játékfilmben folytatódtak (Eva Nová [2015]; Legyen világosság (Nech jesvetlo. 2019)], Jaroslav Vojtek pedig a társadalom peremén élố emberek dokumentumfilmesvizsgálatát (Itt vagyunk [My zdes. 2005]; A határ [Hranica. 2009]; A cigányok szavazni mennek [Cigániidú do volieb. 2012]) játékfilmben (Gyerekek [Deti. 2014]) aknázta ki.

\section{Hajnal szálló}

Ugyanakkor nemcsak a stiláris-formai elemek és a tematikai hasonlóság hozza közös nevezőre a Budapesti Iskolát és az új szlovák dokumentarizmust, hanem társadalmi funkciójuk analógiája is. Mindkét irányzat a korabeli nemzeti filmgyártásból hiányolt politikai-társadalmi reflexió betöltésére hivatott. Amíg Magyarországon a Budapesti Iskola a Szociológiai filmcsoportot! címú 1969-es kiáltványban programszerúen is megfogalmazta a célkitúzéseket, addig Szlovákiában az új szlovák dokumentarizmus az 1990-es évek kulturális vitáiban szorgalmazott társadalmi érzékenységet teljesítette be. Ironikus, hogy miközben a rendszerváltás elsô évtizedében a modern társadalmi problémák szociológiai szinten szinte láthatatlanok maradtak a szlovák filmkultúrában, 
jelenleg teljes pálfordulásként - amint azt Katarína Mišíková megfigyeli - a társadalmi dráma ( socialná dráma) lett a kortárs szlovák film legegységesebb múfaja. ${ }^{[30]}$ Ezek a filmek olyan társadalmilag égetố kérdésekkel néztek szembe, mint a rasszizmus és erôszak (Kutyám, Killer [Môj pes Killer. Mira Fornay, 2013]; Legyen világosság), a romákkal kapcsolatos elôítéletek (Cigány [Cigán. Martin Šulík, 2011]; A cigányok szavazni mennek; Koza [Ivan Ostrochovský, 2015]), az alkoholizmus ( Eva Nová), a szexuális visszaéléseknek a \#metoo mozgalom által katalizált kérdése (Léna [Špina. Tereza Nvotová, 2017]), vagy a többszörös, nyelvi-kulturális-gazdasági peremhelyzet (Itt vagyunk; A határ; Hajnal szálló [Hotel Úsvit. Mária Rumanová, 2017]).

A közép-európai filmmel való második kapcsolódási pont a román újhullám vonatkozásában kristályosodik ki. Eleinte a román film is önnön hátrányából, nevezetesen a financiális támogatás hiányából kovácsolt tôkét magának, és a technikai-infrastrukturális feltételek meghatározták a filmek esztétikai arculatát is: ritkán használ nondiegetikus zenét, eszköztára minimalista, hosszú snittekben gondolkodik, alapvetóen kézikamerát alkalmaz. A pénzügyi hátrányt a kortárs román film invenciózus ötletekkel, virtuóz párbeszédekkel, színvonalas színészi alakítással ellensúlyozta. Úgy vélem, a Generácia 90 úttörô felismerésének köszönhetôen hasonló tendencia zajlott le a szlovák filmben, amely a belsố támogatási rendszer fogyatékosságait fordította a maga előnyére, $\mathrm{s}$ ennek tudható be, hogy a költségigényes játékfilmkészítés helyett elôbb a viszonylag alacsony anyagi ráfordítást igénylő dokumentumfilm, majd az abból kinövő dokumentarista játékfilm lett a kortárs szlovák film domináns vonulata. Ez a tapasztalat már önmagában cáfolja azt az állítást, hogy a 2009-ben létrehozott Audiovizuális Alap jelentette volna a fordulópontot, hiszen a mélyben már megindultak a 2010-es években kiteljesedô, a nemzetközi sikerek felé mutató folyamatok. Az új szlovák dokumentarizmus osztozik a román újhullám intézményi és kulturális jellemzőiben (alacsony költségvetés, dokumentumfilmes jelleg, civil szereplôk, természetes színhelyek), de abban is, hogy - ellentétben a nyugati filmkritika gyakori szúk olvasataival - ezek a román és szlovák filmek nem pusztán a közép-európai nemzetek frusztrációinak, történelmi traumáinak és jelenlegi nyomorúságainak manifesztumai. A konkrét tér- és idôbeli meghatározottságokon túl sokkal általánosabb, emberi tanulságokkal szolgálnak nézôik számára: a 66 szezon nemcsak egy többnemzetiségú közegnek a 20. századi kataklizmákon átívelő túlélési stratégiáiról beszél, hanem a mnemotechnika múködéséról, az elmúlásról és a megbocsátásról; a Vak szerelmek (Slepé lásky. Juraj Lehotský, 2008) nemcsak a társadalmi egyenlôtlenségekrôl, hanem egyetemes szinten a szerelemrôl, a szolidaritásról és a megbékélésrôl; a Koza nemcsak a sportról mint egy roma férfi kitörési lehetôségeirôl, hanem a kitartásról és az újrakezdés lehetôségérôl is szól.

Az alábbiakban röviden két film, a Kutyám, Killer és az Eva Nová címú alkotásokon keresztül szemléltetem, hogyan hasznosította a szlovák dokumentumfilm saját formanyelvét a fikciós játékfilmben.

Kutyám, Killer

Mira Fornay Kutyám, Killer címú filmje arra fókuszál, hogy egy fiatal fiú, aki nélkülözi a meghitt 
családot, hogyan válik szkinheddé és pit bull kutyája révén gyilkossá. Bár groteszk az alapszituáció, amely szerint Marek, a szkinhed azzal szembesül, hogy a féltestvére roma, a film tragédiával végződik. A film tematikailag rokon Fliegauf Bence megtörtént eseményeken alapuló, a 2009-es magyarországi romagyilkosságokra reflektáló Csak a szél (2012) címú munkájával, amely a rendezô addigi stílusának diametrális ellentéte volt. Fornaynál a narratíva fikciós, Fliegaufnál pedig valós gyökerú. Míg utóbbi roma szemszögboól, Fornay egy bôrfejú nézốpontjából láttatja a romagyilkosságot, és az áldozatok nézôpontja helyett a gyilkosság okaira helyezi a hangsúlyt. Mindkét film kézikamerával követi a főszereplôket, amely egyfajta dokumentarista hitelességet kölcsönöz a képeknek. Fornaynál tetten érhetô a természetes színhelyek mikrorealista megfigyelésének dokumentarista módszere, amely a film alacsony költségvetéséból is fakad. További párhuzam, hogy ennek folytán mindegyik minimalista, mellôzi a látványos díszleteket és az epikus akciókat. Fliegaufhoz hasonlóan Fornay is egy amatôrre, egy nem-színészre (Adam Mihál) osztotta a fôszerepet, ami növeli a valószerüség és a hitelesség érzetét. A Kutyám, Killerben a hosszan kitartott, kontemplációra késztetô, mozdulatlan nyitókép megelólegezi az egész filmet jellemzô komorságot, a természetes helyszínek, a lakótelep, a lepukkant kocsma, a grafittis aluljáró és a vidéki szólôskert lefojtott színvilága leíró szociográfiai keresztmetszet is egyszersmind, ami a román újhullámban találhatja meg párját.

A szlovák rendezônő azt a kérdést firtatja, hogyan alakul ki a rasszizmus, és miért lesz valakiből szkinhed. Apró mozaikokon keresztül azt vizsgálja, hogyan vezetnek látszólag jelentéktelen lépések a romagyilkossághoz. Noha Killer, a pitbull marcangolja szét a roma féltestvért, Lukášt, a tettért Marek a felelôs, mert az erôszakkal való játékba bele van kódolva a bûnösség, a gonoszsághoz nem kell szörnyeteggé válni, az is elég, ha a rasszizmussal csak flörtölnek. Fornay játékfilmje olyan, mint egy valódi eseményeket megmutató, a „légy a falon” módszerét alkalmazó voyeurista dokumentumfilm a rutinszerú cselekvések szörnyú következményérôl, illusztrálva a „gondolattalanságot”, amit Hannah Arendt a „gonosz banalitása” kapcsán fejtett ki. [31]

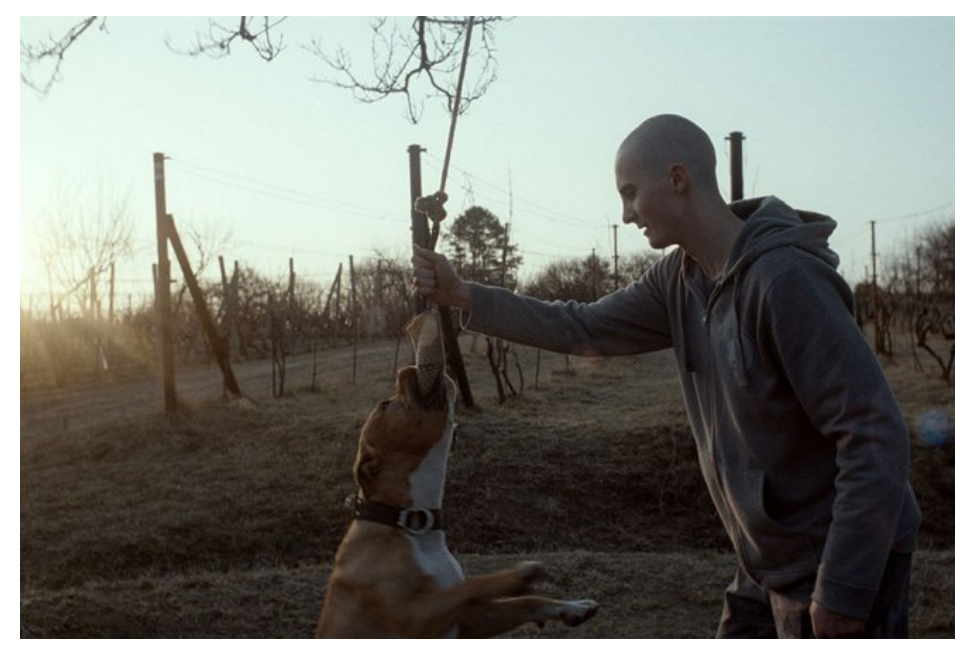

Kutyám, Killer

A pályafutását dokumentumfilmekkel kezdô Marko Škop Eva Nová címú alkotása is a dokumentarista formát adaptálja a fikciós filmre. Škop újságírást és dokumentumfilmkészítést 
tanult az egyetemen, ami tetten érhetô riportszerú dokumentumfilmjeiben, melyeket a terepmunka antropológiai módszere és a szerzôi részvétel jellemez. Amíg ezek közül a lokális/globális feszültségét kutató Más világok még nem volt dramatizált, a centrum/periféria kérdését vizsgáló Telepóchoz már narratív formát választott, amit a rendezố az elsô játékfilmjében, az Eva Novában épített tovább. Az Eva Nová egy elvonókúráról frissen kikerülő idôsödô színésznô kálváriája, aki megpróbál visszailleszkedni a kinti életbe. A rendezô azt a kérdést boncolgatja, hogy vissza lehet-e térni a számúzetésből a bûnbeesés elôtti állapotba, a színészi karrierhez és a családi harmóniához.

\section{Eva Nová}

A dokumentumfilmes örökség az eszköztelenségben mutatkozik meg: a film természetes helyszíneken játszódik Sabinovban és Petržalkán (Pozsony 5. kerülete), mellôzi a zenehasználatot (egyetlen kivétel, amikor karrierjének egyfajta búcsúdalaként a fôszereplô, Eva Nová Karel Gott C'est la vie cimú sanzonját hallgatja), a képkivágat többnyire csak a szereplök körüli szúk térre korlátozódik, a párbeszédek életszerúek. A statikus kamera által megmutatott szúk, zárt terek Michael Haneke és Ulrich Seidl rideg stílusával ápolnak rokonságot. A mikrorealista megfigyelések dokumentarista módszerét azonban Škop kimondottan játékfilmekre jellemzô fikciós összetevốkkel kombinálja: a film világos dramaturgiai ívvel, megszerkesztett kezdôponttal (a fôszereplő színésznô épp kilép a rehabilitációs intézetből) és végponttal rendelkezik (a film zárlatában Eva Nová, az alkoholista anya és Ďodo, a fia fanyar módon egymásra talál). Ugyancsak eloldják a filmnyelvet a dokumentarista módszertôl a vizuális metaforaként múködô markáns képi kompozíciók. Ilyen az, amikor a kamerához frontálisan beszélô színésznô idôs arcát együtt látjuk a falon lévô fiatalkori poszterével, keresztezve és ellenpontozva egymással a múltbeli sikert és a jelen sivárságát. De vizuálisan erôs jelképet alkalmaz a zárójelenet is, amelyben az anyát és a fiút együtt látjuk úszkálni egy kerti medencében: látszólag helyreáll a családi harmónia, amely a happy end felé terelné a végkifejletet, csakhogy a víz felszínén ott úszik egy alkoholos palack. Maga a címválasztás is szimbolikus, mivel az „Eva Nová”, a fôszereplô díva tulajdonneve szlovákul „új Évát” jelent, ami bibliai konnotációval ruházza fel a filmet. Az ótestamentumi intertextus mitológiai síkra emeli a korosodó színésznô történetét, amennyiben a film a nő alkoholizmusát paradicsomkerti bûnbeesésként, színésznôi mellôzöttségét pedig a bibliai édenkertbôl való számúzetésként értelmezi újra. A kert az elkorcsosult édenkert bibliai metaforájává súlyosbodik, ahová lehetetlen a visszatérés. Ez az erôteljes metaforahasználat, valamint az, hogy Škop Fornayval szemben egy ismert, professzionális színésznôre (Emília Vášáryová) osztotta a fôszerepet (bár a szerep és a színész karaktere közel áll egymáshoz), eltávolítja a filmet a dokumentarizmustól.

Mind a Kutyám, Killer, mind az Eva Nová osztozik a minimalista esztétikában, de, mint látható, a dokumentumfilmes és a fikciós módszereket ellentétes irányba fejlesztik tovább. 


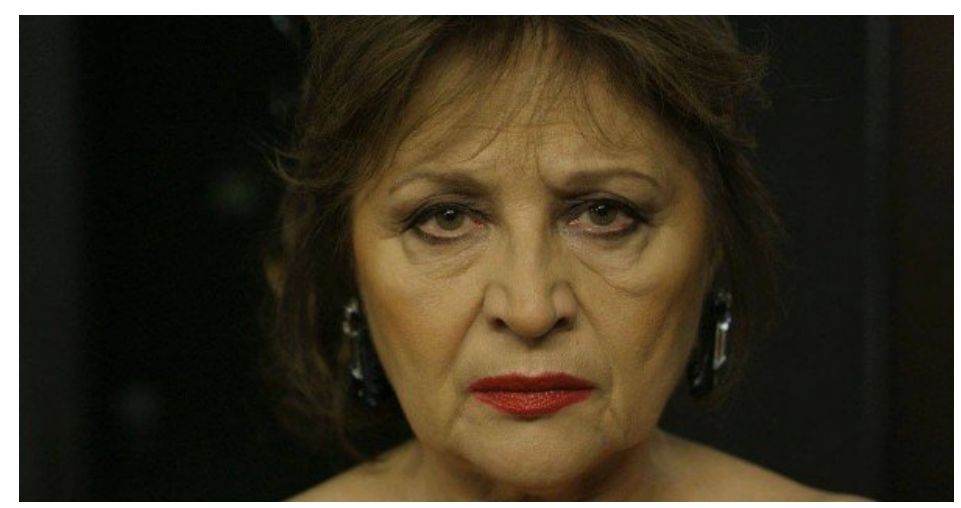

Eva Nová

\section{Romareprezentáció és közép-európai posztkolonializmus}

Speciális témakörét képviseli a 90-es nemzedék által életre keltett új szlovák dokumentarizmusnak a roma kisebbség ábrázolása. Az alábbiakban azt igyekszem demonstrálni, hogy az új szlovák dokumentarizmus olyan témákkal, mint a romakérdés, maga mögött hagyta a Jana Dudková által említett „megkésettséget” és „anakronizmust”, és párbeszédképessé tette a szlovák filmet a kortárs nemzetközi áramlatokkal.

A szlovák film története bôvelkedik a romák ábrázolásában. Dušan Hanák Rózsaszin álmok (Ružové sny. 1977) címú lírai-romantikus filmje nemzetközileg is úttörőnek számított abban, hogy a kisebbségekkel szembeni, sztereotípiák által táplált elôítéletekkel nyíltan foglalkozott. A szlovák „romafilm” heterogén kontextusát és széles tradícióját jelzi, hogy Juraj Jakubisko Szökevények és zarándokok (Zbehovia a pútnici. 1968) címú filmje filozófiai allegóriában mutatta meg a romákat, a Koza sportfilm keretében tárgyalja a helyzetüket, Martin Šulík Cigány címú filmje és Ladislav Kaboš Az összes gyermekem (Všetky moje deti. 2013) címú munkája hiperrealista megközelítést alkalmazva fókuszált az életükre. Szociológiai problémák megragadására vállalkozott a Roma ház (Rómsky dom. Marko Škop, 2001), az Aš városáig (Až do mesta Aš. Iveta Grófová, 2012) és a Hajnal Szálló, míg a roma Holokausztra fókuszált a Lyuk a fejben (Diera v hlave. Robert Kirchhoff, 2017). Véleményem szerint ezen filmek értelmezéséhez kitûnô szempontokat kínálhatnának a posztkolonializmus elméletei, melyeket ugyan fóként, bár szúken a „harmadik világra” szoktak használni, de Edward Said, Gayatri Chakravorty Spivak, Homi K. Bhabha vagy R. Siva Kumar meglátásai éppúgy érvényesíthetôk az etnikai kisebbségeket, egyéni kultúrákat a történelem során folyamatosan és kölcsönösen elnyomó közép-európai országokra, népekre is. Végsô soron ennek alkalmazására a másik oldalról mutat példát a bolgár Alexander Kiossev kiterjedt munkássága is. Csatlakozva Imre Anikó véleményéhez, aki szintén a posztkoloniális elméletek meghonosítását szorgalmazta a régiós filmre vonatkoztatva, kétségtelen, hogy a „posztszocialista régió egyúttal posztkoloniális is”. ${ }^{[32]}$ Most két filmben vizsgálom a „minor film” [33] és a posztkoloniális megközelítések alternatív lehetőségeit. 


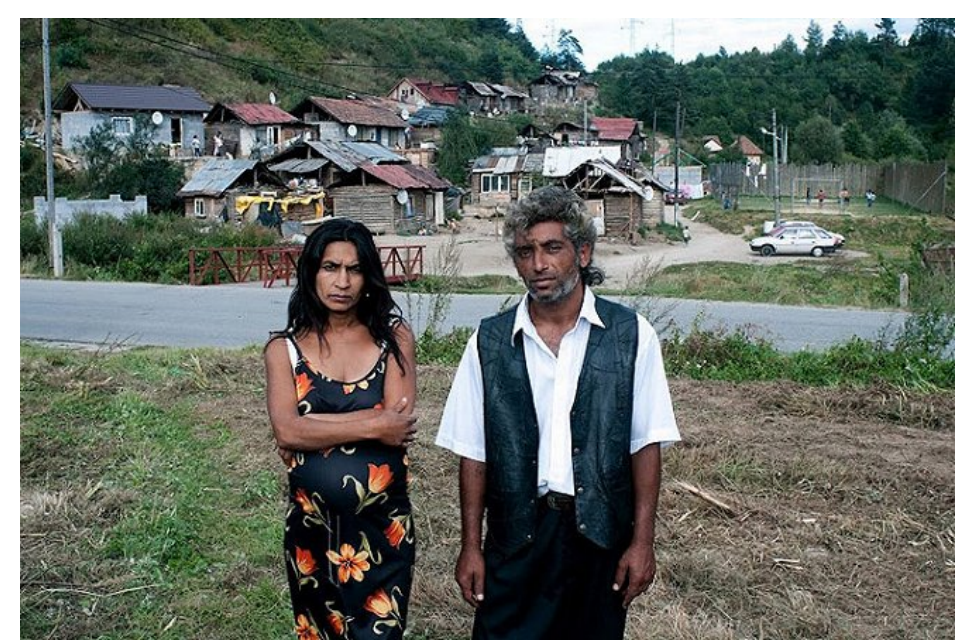

A boldogság csengöi

Jana Bučka és Marek Šulík filmje, $A$ boldogság csengői (Zvonky štastia. 2012) nem a hagyományos romareprezentációt örökíti tovább, mivel a roma témát a rajongói kultúrával keresztezi. A boldogság csengối a cigányság kultúráját és többszörösen hátrányos szociális helyzetét nem pusztán a kulturális másság, a társadalmi elôítéletek vagy a rasszista megbélyegzettség felól vizsgálja. A szociográfiai vagy etnográfiai megközelítések dominanciája helyett a társadalmi és gazdasági emancipáció vágyától a populáris kultúra, a szubkultúra, a multikulturalizmus, a virtuálisvalóságépítés és a transznemúség problémáján át számos kérdést feszeget. Az alaptörténet szerint a két peremhelyzetben élô roma, Mariena és Roman a cseh Karel Gott és a szlovák Darina Rolincová rajongói, akik az egyik tehetségkutató músort nézve elhatározzák, hogy az általuk elōadott popdalról, az 1984-ben született Zvonky štastia (csehül: Zvonky štěstî) címú régimódi számról videoklipet forgatnak, és azt elküldik az énekeseknek. A dal strófái - a csehszlovákizmus hivatalos ideológiájának tömegkulturális propagandájaként - eredetileg felváltva csehül és szlovákul hangzottak el, a filmben a két fôszereplô azon vitatkozik, hogy a dalt csehül, szlovákul vagy roma nyelven énekeljék-e. Mariena és Roman megszállottan vagdossák ki a bulvárújságokból a két énekes képét. Vallásos imádatukat jelzi, hogy a házban jól megférnek a szakrális kegytárgyak Karel Gott legyek lepte poszterével - mely ironikusan felidézi Ferenc József császár légyürülékkel telepiszkított arcképét a Švejkból. Kilátástalan élethelyzetüket imaginárius módon kompenzálják, vágyaikat képzeletben élik ki, így a film a romareprezentáció szociográfiáját a szenvedélyes gyújtögetés, a bálványimádás, az identitáskeresés kérdésével párosítja össze.

A boldogság csengôi 
A rajongói kultúra, mely extrém vonzalmat érez hírességei iránt és elôszeretettel bújik azok bôrébe, többrétegúvé teszi $A$ boldogság csengôi társadalmi drámáját. A filmszociográfia felé mutat a dokumentarista megközelítés, a kézikamera használata, a filmkészítôknek az adott közösségbevaló familiáris beolvadása pedig a "résztvevô megfigyelés” antropológiai módszereit implikálja. A mélyszegénységet, a gyertyafénnyel tompán megvilágított szobát a két sztárénekes reflektorfényével ellenpontozó film a nyomort speciális módon a popkultúrán keresztül tárja fel, de egyúttal túl is mutat a szokványos kérdésfelvetéseken.

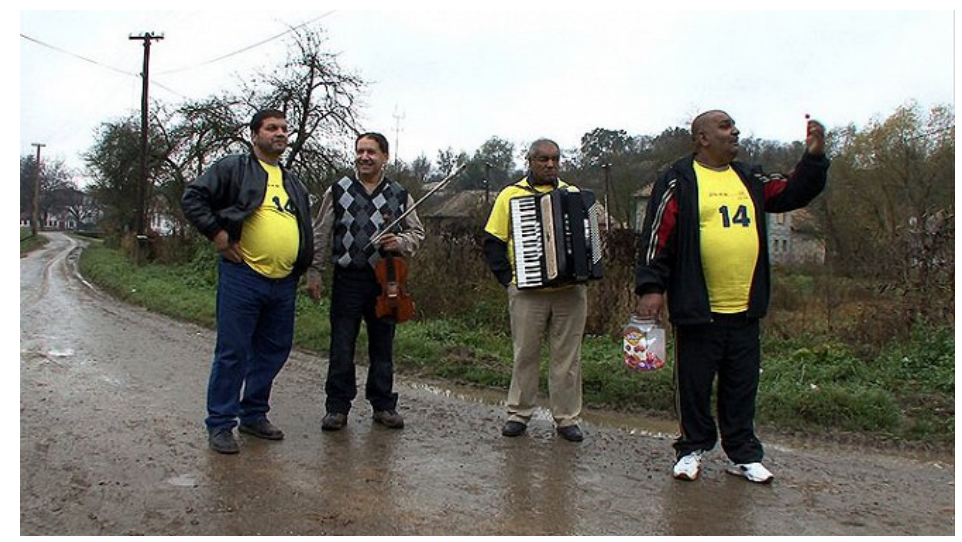

A cigányok szavazni mennek

Šulík és Bučka múvéhez hasonlóan eltér a hagyományos romaábrázolásoktól Jaroslav Vojtek a szlovákiai romák politikai képviseletét középpontba állító A cigányok szavazni mennek címú filmje is. Úgy mulatságos (vagy tragikomikus), hogy elkerüli az Emir Kusturica filmjeihez társított, bahtyini értelemben vett karneváli regiszter bohózatba fordulását, nem nézi le, de nem is idealizálja cigány (anti)hőseit. A fikciós és nem fikciós eljárások vegyítésével Vojtek filmje Vlado Sendreit, a neves szlovákiai roma zenészt annak választási kampányán kíséri el. Sendrei 2009-ben valóban indult a szlovákiai választásokon, és ennyiben a film a dokumentumfilm hagyományait követi. A jelölés folyamatától a politikai kampányon át a választási bukásig tartó dramaturgiai ív azonban láthatóan a játékfilm elbeszélói sémája szerint épül fel. A kamera - olykor erôsen emlékeztetve a brit kitchen sink realizmusára - az események résztvevójévé válik, és inkább analitikusan közelíti meg tárgyát, mintsem hogy ítélethozatalra törekedne.

Az ellentétes regiszterek használatát, a komikus és tragikus elemek kombinációját, amely a cseh/szlovák filmek hosszú tradíciójába ágyazódik, nem feltétlenül szerencsés csupán abból a szempontból értelmezni, hogy mennyiben örökíti tovább a sztereotip ábrázolást vagy közvetít negatív képet a romákról. Ahelyett, hogy a pozitív és negatív imázsok bináris logikáját tartanánk folyton szem elốtt a romaábrázolások esetében, termékenyebbnek gondolom a posztkoloniális elmélet meglátásainak meghonosítását a roma filmek esetében, éppúgy, ahogyan maga az antropológia tudományága is hazatelepült „egzotikus” helyekrôl a nyugati világba. Gayatri C. Spivaknak az ábrázolhatatlanságra vonatkozó klasszikus kérdése (Can the subaltern speak?/Szóra birható-e az alárendelt?), a gyarmatosító és a gyarmatosított közötti átmenetek, a Homi K. Bhabha által leírt kulturális elkülönböződés (cultural diversity) és a hidriditás elméletei olyan támpontokat 
nyújthatnak a közép-európai romareprezentációk posztkoloniális értelmezéséhez, melyeket eddig kevésbé vettek számításba a kortárs romafilmes diskurzusokban. Úgy vélem, hogy a kulturális kolonizáció révén létrehozott hibriditás és képlékeny identitások $A$ cigányok szavazni mennek egyik alapproblémáját jelenti.

\section{A cigányok szavazni mennek}

Posztkoloniális kontextusban sokatmondó, hogy a roma identitás megkonstruálása során a film szereplói minduntalan a multikulturalizmus és a heterogén kulturális sajátosságok kérdéseivel találják szembe magukat. A széles nyilvánosság elôtt Vlado Sendrei romaként pozicionálja magát, és azzal a céllal vág neki a politikai karriernek, hogy mandátumával a szlovákiai romákat politikai képviselethez juttassa. Az etnikai alapú politikai gyakorlattal szemben azonban a jelölt és stábja folyamatosan azzal kénytelen szembesülni, hogy egyáltalán nem világos, hogy kik és milyen tulajdonságok nyomán nevezhetôk romának, és hogy mennyire képlékeny a roma identitás, mivel a kolonizáló és a kolonizált közötti cserefolyamatok következtében hibrid identitásformák jöttek létre. Ilyenformán a „roma közösség” címke egy belülrôl is tagolt, heterogén csoportra utal, a „roma képviselet” hívószava pedig már eleve gyarmatosító fogalom, amely újabb alárendeltségi viszonyokat, elnyomott, kisebbségi identitásokat termel ki magából. Burkolt öngyarmatosításra és mindenféle sztereotípia abszurditására mutat rá a film azon jelenete, amikor a roma kampánystáb sárga pólóban indul a választási hadjáratba, és elhangzik, hogy a sárga szín azért nem megfelelô, mert az úgyszólván „nem cigány szín” (ez internalizált rasszizmusként is értelmezhetô). A kisbuszban folytatott beszélgetések arra világítanak rá, hogy mennyire nem egyértelmú ez az identitáspolitika, és hogy a szlovákiai romák többszörös identitásokat is magukénak vallhatnak. Az etnikai, nyelvi és kulturális sokszínûséget és az identitás rögzíthetetlen voltát példázzák azok a groteszkbe forduló párbeszédek, amelyek során többek között a roma kampánystáb egyik tagjától szemrehányóan azt kérdezik a többiek, hogy ô roma-e egyáltalán vagy szlovák, mire az a csattanós válasz érkezik, hogy „szlovák roma vagyok, de magyarul beszélek”. A helyzet humoros és abszurd voltát felerôsítik a kimondottan játékfilmes megoldásokra utaló montázsok. Miközben ugyanis éppen az identitásról zajlik a vita, a párbeszédeket az út mentén elhelyezett óriásplakátokról készült vágóképek szakítják meg, melyeken a szlovák szélsójobboldalnak a nyelvi homogenitás vágyát hirdetô jelszavai olvashatók, mint például a Pozsony? Nie, Bratislava! (Nem Pozsony, hanem Bratislava!).

Miközben tehát a politikai ideológia szintjén a szélsőjobb és a roma identitáspolitika egyaránt homogenitásra tör, a mindennapi élet gyakorlati szintjén a rögzített identitást a nyelvi-kulturális hibridizáció valójában örökre felszámolta. A nyelvi, etnikai és kulturális keveredés hatására többszörös és hibrid identitások jöttek létre, a homogenitás fikciója helyét a heterogenitás foglalta el, aminek következményei a posztkoloniális (film)elméletek Közép-Európára való alkalmazását sürgetik. 


\section{Szlovák újhullám 2.0?}

Az úgynevezett 90-es nemzedék által elindított új szlovák dokumentarizmus jelentôsége abban ragadható meg, hogy újra felhelyezte a szlovák filmmúvészetet a nemzetközi filmes térképre, és az 1960-1970-es évekbeli „szlovák újhullámhoz” hasonlítható virágzást hozott el. Története során a szlovák film mindig is a folyamatosság hiányával küszködött, a szlovák újhullám is torzóban maradt az 1968-as szovjet katonai invázió és az azt követô husáki „normalizáció” következtében. Derékba tört életmúvek, mozgalmak, elszigetelt kísérletek, folytonos újrakezdések után az elmúlt húsz évben nyílt csak elôször tartós lehetôsége a szerves gyarapodásra. E „bársonyos regeneráció“ nyomán az új szlovák dokumentarizmus hasonlóan erôs múveket alkotott, mint az elsố szlovák újhullám, ezért nem tûnik túlzásnak ezt „második szlovák újhullámnak“ felcímkézni. Az új szlovák dokumentarizmus belsố elôzményei között tarthatók számon többek között Dušan Hanák dokumentumfilmet és játékfilmet ötvöző filmjei vagy Štefan Uher amatốr szinészei. Hanák és az etnofilmes Martin Slivka, a pályájukat a 60-as években kezdô jelentôs rendezôk lettek késôbb a 90es nemzedék tagjainak a tanárai a pozsonyi egyetemen. Esetükben személyi szinten is megfigyelhetố a folytonosság a két szlovák újhullám között. Eközben a szlovák film szinte teljes pálfordulást hajtott végre: míg a 90-es években a kritika a nemzeti film eszképizmusát bírálta és a társadalmi érzékenységet hiányolta belóle, mára a „társadalmi dráma” lett a vezetô múfaj. Sốt Zuzanna Piussi, és különösen a fikciós dokumentarizmust új szintre emelô Mariana ČengelSolčanská munkái (Emberrablás [Únos. 2017]; Disznó [Sviňa. 2020]) révén a film legújabban a politikai aktivizmus részévé is vált, amely már nemcsak reflektál az aktuális közügyekre, hanem alakítja is azokat.

[A tanulmány angol nyelvú változatát jelen tematikus számban közöljük]

\section{Jegyzetek}

1. A tanulmány újragondolása és jelentôsen kibôvített változata korábbi rövid esszémnek: Gerencsér Péter (2018): Kertektôl a közügyekig. Filmvilág, 62. évf. 4. sz. 38-41.

2. Mazierska, Ewa (2010): Eastern European Cinema: Old and New Approaches. Studies in Eastern European Cinema, vol. 1. no. 1. 5-16.

3. Hames, Peter (2010): The Czech and Slovak Cinema: Theme and Tradition. Edinburgh, Edinburgh University Press. 223.

4. Palúch, Martin (2015): Autorský dokumentárny film na Slovensku po roku 1989. Bratislava, Vlna.

5. Václav Klaus 2003 és 2013 között volt a Cseh Köztársaság elnöke.

6. Hames: i. m. 12.

7. Dudková, Jana (2014): Contamporary Slovak Film: A Symptom of the Times or a Represenation of Society. Ford. Jozef Ferencz. Slovenské divadlo. 62. sz. 40-53.

8. Dudková: i. m. 41. - Nem szabad elfelejtenünk, hogy a filmgyártás Csehszlovákiában 1993-ig állami monopólium volt, a kommunizmus összeomlása után is, ami azt jelenti, hogy a magánprodukciók (elméletileg) törvényellenesek voltak, azaz még intézményi szempontból sem történt meg a váltás. 
9. Dudková: i. m. 42.

10. Gelencsér Gábor (2014): Hagyományos újítás. Az ezredforduló „fiatal magyar filmje”. In Uô: Az eredendô máshol. Magyar filmes szólamok. Budapest, Gondolat, 320-324.

11. A mozgalomról összefoglalóan: Pop, Doru (20149: Romanian New Wave Cinema: An Introduction. Jefferson, McFarland.

12. Goscilo, Helena -Holmgren, Beth (szerk.) (2021):Polish Film Today: A Bold New Era in Film. London, Rowman \& Littlefield.

13. Kováč, Dušan (2001): Szlovákia története. Pozsony, Kalligram, 317. A vonatkozó részt fordította H. Tóth Ildikó.

14. A támogatási alap alapelveit lásd az interneten http://www.avf.sk/english.aspx

15. Dudková: i. m. 41.

16. Branko, Pavel (2004): Slovenský dokumentárny film - Generácia 90. Film.sk, 5. évf. 2. sz. 22-24.

17. Hames, Peter (2001): Bratislava and Beyond. Central Europe Review, 3. évf. 3. sz.

18. A csehszlovák újhullámos film fogalma nem keverendô össze a szlovák újhullámmal. Habár vitatott, milyen mértékben tekinthetô a szlovák újhullám önállónak, és az elnevezés mennyiben egyenrangú a csehszlovák és a francia újhulláméval, mind a szlovák filmtörténet, mind a nemzetközi szakirodalom használja a terminust. Grandiózus filmtörténeti panorámájában a Jelena Paštéková és Václav Macek szerzôpáros azoknak az új szemléletû, generációs jellegú szlovák rendezóknek (Juraj Jakubisko, Dušan Hanák, Elo Havetta) a szerzői filmjeit sorolja ide, akik a hatvanas évek végén kezdték formálni a különálló mozgalmat, de ezt derékba törte az 1968-as szovjet bevonulás és azt követô „normalizáció” (Macek, Václav - Paštéková, Jelena (2016): Dejiny slovenskej kinematografie. 1896-1969. Bratislava, Slovenský filmový ústav / FOTOFO / Stredoeurópsky dom fotografie. 484-485.). Ilyen értelemben különálló jelenségként tárgyalja a szlovák újhullámot Jonathan L. Owen, aki szerint a nemzetközi kapcsolatok megerôsödése, a folklór szerepe és az avantgárd tendenciák teremtik meg az önálló fogalom létjogosultságát [Owen, Jonathan L.: Flight From History: Otherness, Politics and Folk Avant-Gardism in Juraj Jakubisko's The Deserter and the Nomads (1968) and Birds, Orphans and Fools (1969). In Uô (2011): Avant-garde to New Wave: Czechoslovak Cinema, Surrealism and the Sixties. New York / Oxford, Berghahn Books, 129-130.]. Ráadásul a szlovák filmgyártás növekvố autonómiája - fôként Albert Marenčin intézményi irányítása révén - kifejezetten szorgalmazta a „nagyobb testvér” csehek kolonizáló hatásától való megszabadulást, amely többek között szlovák alkotók és Alain Robbe-Grillet közös filmjeit eredményezte [Owen, Jonathan L. (2013): Alain Robbe-Grillet in Slovakia: Transnational Encounters and the Art of the Co-Production. Iluminace, 25. évf. 4. sz. 63-77.].

19. Dudková: i. m. 42 .

20. Branko: i. m. 22-24.

21. Bosáková, Žofia (2016): Generácia 90. Slovenské divadlo, 64. évf. 4. sz. 385-396.

22. Bosáková: i. m. 388.

23. Bosáková: i. m. 391.

24. Palúch: i. m.

25. Gerencsér Péter (2017): Alter/natív identitások. A szlovák film transznacionalitása. Metropolis, 21. évf. 4. sz. $37-38$.

26. Összefoglalóan lásd: Gelencsér Gábor (2002): A Titanic zenekara. Stílusok és irányzatok a hetvenes évek magyar filmmüvészetében. Budapest, Osiris, 244-263. Szélesebb kontextusban: Gelencsér Gábor (2013): Csend és kiáltvány: A fikciós dokumentarista forma hagyománya. Apertúra, 8. évf. 3. sz. http://uj.apertura.hu/2013/tavasz/gelencser-csend-es-kialtvany-a-fikcios-dokumentarista-forma- 
hagyomanya/

27. Dudková, Jana (2013): Cultural Memory in Representations of Central Europe: The Case of Slovak Cinema after 1989. ШШШ口/ Cultsure83-84.

28. Ferenčuhová, Mária (2014): Metaphor, Metonymy and Metalepsis: Three Tropes in Contemporary Slovak Documentary. Images. The International Journal of European Film, Performing Arts and Audiovisual Communication, 15. évf. 24. sz. 29-34.

29. Gerencsér Péter (2019): Újraforgatott történelmek. Kerekes Péter filmjei. Dunszt.sk, https://dunszt.sk/2019/07/31/ujraforgatott-tortenelmek/

30. Mišíková, Katarína (2015): Hl’adanie žánru v súčasnom slovenskom hranom filme. In Nový slovenský film produkčné, estetické, distribučné a kritické východiská. Szerk. Mišíková, Katarína - Ferenčuhová, Mária. Bratislava, Vysoká škola múzických umení Bratislava, Filmová a televízna fakulta, 29-36.

31. Az antiszemitizmus és a romaellenesség logikájának összefüggését a Kutyám, Killer és az Oscar-díjas (cseh)szlovák Holokauszt-film, az Üzlet a korzón (Obchod na korze. Ján Kadár és Elmar Klos, 1965) kapcsán vizsgáltam: Gerencsér Péter (2017): Nielen vietor. Ford. Galina Sándorová. Vlna, 70. https://www.vlna.sk/nielen-vietor/

32. Imre Anikó (2014): The Case for Postcolonial, Postsocialist Media Studies. Boundary, 41. évf. 1. sz. 113-134. https://doi.org/10.1215/01903659-2409694

33. A „minor cinema” fogalmát Tom Gunning vezette be: Gunning, Tom (1989-1990): Towards a Minor Cinema: Fonoroff, Herwitz, Ahwesh, Klahr, Lapore and Solomon. Motion Picture, 3. évf. 1-2. sz. 2-5.

\section{Irodalomjegyzék}

- Bosáková, Žofia (2006): Generácia 90. Slovenské divadlo, 64. évf. 4. sz. 385-396.

- Branko, Pavel (2004): Slovenský dokumentárny film - Generácia 90. Film.sk, 5. évf. 2. sz. 22-24.

- Dudková, Jana (2013): Cultural Memory in Representations of Central Europe: The Case of

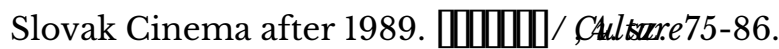

- Dudková, Jana (2014): Contamporary Slovak Film: A Symptom of the Times or a Represenation of Society. Ford. Jozef Ferencz. Slovenské divadlo. 62. sz. 40-53.

- Ferenčuhová, Mária (2014): Metaphor, Metonymy and Metalepsis: Three Tropes in Contemporary Slovak Documentary. Images. The International Journal of European Film, Performing Arts and Audiovisual Communication, 15. évf. 24. sz. 29-34.

- Gelencsér Gábor (2002): A Titanic zenekara. Stílusok és irányzatok a hetvenes évek magyar filmmúvészetében. Budapest, Osiris.

- Gelencsér Gábor (2013): Csend és kiáltvány: A fikciós dokumentarista forma hagyománya. Apertúra, 8. évf. 3. sz. http://uj.apertura.hu/2013/tavasz/gelencser-csend-es-kialtvany-a-fikciosdokumentarista-forma-hagyomanya/

- Gelencsér Gábor (2014): Hagyományos újítás. Az ezredforduló „fiatal magyar filmje”. In Uô: Az eredendô máshol. Magyar filmes szólamok. Budapest, Gondolat, 320-324.

- Gerencsér Péter (2017): Alter/natív identitások. A szlovák film transznacionalitása. Metropolis, 21. évf. 4. sz. 22-42.

- Gerencsér Péter (2017): Nielen vietor. Ford. Galina Sándorová. Vlna, 70. https://www.vlna.sk/nielen-vietor/

- Gerencsér Péter (2018): Kertektôl a közügyekig. Filmvilág, évf. 4. sz. 38-41. 
- Gerencsér Péter (2019): Újraforgatott történelmek. Kerekes Péter filmjei. Dunszt.sk, https://dunszt.sk/2019/07/31/ujraforgatott-tortenelmek/

- Gunning, Tom (1989-1990): Towards a Minor Cinema: Fonoroff, Herwitz, Ahwesh, Klahr, Lapore and Solomon. Motion Picture, 3. évf. 1-2 sz. 2-5.

- Hames, Peter (2001): Bratislava and Beyond. Central Europe Review, 3. évf. 3. sz.

- Hames, Peter (2010): The Czech and Slovak Cinema: Theme and Tradition. Edinburgh, Edinburgh University Press.

- Imre Anikó (2014): The Case for Postcolonial, Postsocialist Media Studies. Boundary, 41. évf. 1. sz. 113-134. https://doi.org/10.1215/01903659-2409694

- Kováč, Dušan (2001): Szlovákia története. Pozsony, Kalligram.

- Macek, Václav - Paštéková, Jelena (2016): Dejiny slovenskej kinematografie. 1896-1969. Bratislava, Slovenský filmový ústav / FOTOFO / Stredoeurópsky dom fotografie.

- Mazierska, Ewa (2010): Eastern European Cinema: Old and New Approaches. Studies in Eastern European Cinema, vol. 1. no. 1. 5-16.

- Mišíková, Katarína (2015): Hladanie žánru v súčasnom slovenskom hranom filme. In: Nový slovenský film - produkčné, estetické, distribučné a kritické východiská. Szerk. Mišíková, Katarína - Ferenčuhová, Mária. Bratislava, Vysoká škola múzických umení Bratislava, Filmová a televízna fakulta. 9-36.

- Owen, Jonathan L. (2011): Flight From History: Otherness, Politics and Folk Avant-Gardism In Juraj Jakubisko's The Deserter and the Nomads (1968) and Birds, Orphans and Fools (1969). In Uô: Avant-garde to New Wave: Czechoslovak Cinema, Surrealism and the Sixties. New York / Oxford, Berghahn Books, 129-156.

- Owen, Jonathan L. (2013): Alain Robbe-Grillet in Slovakia: Transnational Encounters and the Art of the Co-Production. Iluminace, 25. évf. 4. sz. 63-77.

- Palúch, Martin (2015): Autorský dokumentárny film na Slovensku po roku 1989. Bratislava, Vlna.

- Pop, Doru (2014): Romanian New Wave Cinema: An Introduction. Jefferson, McFarland.

\section{Filmográfia}

- 322 (Dušan Hanák, 1969)

- 66 szezon (66 sezón. Kerekes Péter, 2003)

- 98 hangja (Hlas 98. Marek Kuboš, 1998)

- A boldogság csengôi (Zvonky štastia. Jana Bučka és Marek Šulík, 2012)

- A cigányok szavazni mennek (Cigáni idú do volieb. Jaroslav Vojtek, 2012)

- A dévényi mészárlás (Devinsky masaker. Gejza Dezorz, 2011)

- A harmadik hatalmi ág betegsége (Nemoc tretej moci. Zuzana Piussi, 2011)

- A határ (Hranica. Jaroslav Vojtek, 2009)

- A kert (Záhrada. Martin Šulík, 1995)

- Aš városáig (Až do mesta Aš. Iveta Grófová, 2012)

- Az összes gyermekem (Všetky moje deti. Ladislav Kaboš, 2013)

- Bársonyos terroristák (Zamatoví teroristi. Peter Kerekes, Ivan Ostrochovský, Pavol Pekarčík, 2013)

- Cigány (Cigán. Martin Šulík, 2011) 
- Családi tûzfészek (Tarr Béla, 1977)

- Csak a szél (Fliegauf Bence, 2012)

- Csépló Gyuri (Schiffer Pál, 1978)

- Disznó (Sviňa, Mariana Čengel-Solčanská, 2020)]

- Emberrablás (Únos. Mariana-Čengel-Solčanská, 2017)

- Egy régi világ képei (Obrazy starého sveta. Dušan Hanák, 1972)

- Eva Nová (Marko Škop, 2015)

- Ficótól Ficóig (Od Fica do Fica. Zuzana Piussi, 2012)

- Gyerekek (Deti. Jaroslav Vojtek, 2014)

- Hajnal szálló (Hotel Úsvit, Mária Rumanová, 2017)

- Hogyan fó a történelem? (Ako sa varia dejiny. Peter Kerekes, 2008)

- Itt vagyunk (My zdes. Jaroslav Vojtek, 2005)

- Jutalomutazás (Dárday István és Szalai Györgyi, 1974)

- Koza (Ivan Ostrochovský, 2015)

- Köszönöm, jól (Ďakujem, dobre. Prikler Mátyás, 2013)

- Kutyám, Killer (Môj pes Killer. Mira Fornay, 2013)

- Legyen világosság (Nech je svetlo. Marko Škop, 2019)

- Léna (Špina. Tereza Nvotová, 2017)

- Lyuk a fejben (Diera v hlave. Robert Kirchhoff, 2017)

- Orbis Pictus (Martin Šulík. 1997)

- Más világok (Iné svety, Marko Škop, 2006)

- Minden, amit szeretek (Všetko čo mám rád. Martin Šulík, 1993)

- Rivers of Babylon (Vladimír Balco, 1998)

- Roma ház (Rómsky dom. Marko Škop, 2001)

- Rózsaszín álmok (Ružové sny. Dušan Hanák, 1977)

- Szabadgyalog (Tarr Béla, 1980)

- Szlovákia 2.0 (Slovensko 2.0. Ondrej Rudavský, Martin Šulík, Viera Čákanyová, Zuzana Liová, Mišo Suchý, Juraj Herz, Miro Jelok, Peter Krištúfek, Iveta Grófová, Peter Kerekes, 2014)

- Szökevények és zarándokok (Zbehovia a pútnici. Juraj Jakubisko, 1968)

- Telepóc (Osadné. Marko Škop, 2009)

- Vak szerelmek (Slepé lásky. Juraj Lehotský, 2008) 
(C) Apertúra, 2021. Ỗsz | www.apertura.hu

webcím: https://www.apertura.hu/2021/osz/gerencser-barsonyos-regeneracio-az-uj-szlovak-

dokumentarizmus-az-ezredfordulo-utan/

https://doi.org/10.31176/apertura.2021.17.1.4

(2)opertúro 